Supporting Information for

\title{
Arsenic Drinking Water Violations Decreased Across the United States Following Revision of the Maximum Contaminant Level
}

Stephanie A. Foster ${ }^{1}$, Michael J. Pennino², Jana E. Compton ${ }^{3}$, Scott G. Leibowitz ${ }^{3}$, Molly L. Kile ${ }^{1}$

${ }^{1}$ College of Public Health and Human Sciences, Oregon State University, Corvallis, Oregon 97331, United States

${ }^{2}$ US EPA, Office of Research and Development, National Center for Environmental Assessment, Washington, DC 20460, United States

${ }^{3}$ US Environmental Protection Agency, National Health and Environmental Effects Research Laboratory, Western Ecology Division, Corvallis, Oregon 97333, United States

*Corresponding author e-mail: fosters2@oregonstate.edu

\section{DESCRIPTION OF SUPPORTING INFORMATION}

Table S1. Metrics for PWS arsenic violations obtained from EPA's SDWIS.

Table S2. Arsenic removal treatment methods incorporated into treatment analysis of violating systems and the average annual number of systems with arsenic violations reporting each treatment between 2013-2017.

Table S3. Number and percent of violations and mean population served for all PWS and by water source, PWS type, and owner type during period of 2006 to 2017.

Table S4. Mean annual number of systems in FAR violation and annual percent of systems in FAR violation by state within the conterminous US. States with "NA" values had no recorded health-based violations during the 2006-2017 time period. Alaska and Hawaii excluded from the analysis.

Table S5. The range of systems in FAR violation, the most recent number of systems in violation, and the percent reduction of the number of systems in violation per state within the conterminous US over the 
time period 2006-2017. States with "NA" values had no recorded health-based violations during this period but did have monitoring or reporting violations (not shown here). Alaska and Hawaii excluded from the analysis.

Figure S1. The percent of PWS (CWS and NTNCWS) in violation for arsenic (exceedance of MCL) by system type between 2006 and 2017.

Figure S2. Comparison of the percent of PWS in FAR violation between 2006 and 2017 for either monitoring/reporting or a health-based violation (exceeding the $10 \mu \mathrm{g} / \mathrm{L} \mathrm{MCL}$ ). Both violation types demonstrate significant downward trends over time. Monitoring/Reporting: $p<0.05$, slope $=-0.054$; Health-Based: $p<0.001$, slope $=-0.070$.

Figure S3. The mean number of discontinued facilities for PWS from 2014 to 2017, stratified by those in violation and those no longer in violation. 
Table S1. Metrics for public water system (PWS) arsenic violations obtained from EPA's Safe Drinking Water Information System (SDWIS). See footnotes ${ }^{a, b}$.

Metric Calculation Method

\section{Temporal Metrics}

\begin{tabular}{|c|c|}
\hline Number of Systems in & Number of PWS with at least one violation in a particular calendar \\
\hline Violation & $\begin{array}{l}\text { year. No PWS in violation is counted more than once per year, even } \\
\text { if it has a violation in multiple quarters per year. }\end{array}$ \\
\hline Percent of Systems in & Number of systems in violation for a calendar year divided by the \\
\hline Violation & $\begin{array}{l}\text { inventory of active systems for that fiscal year (beginning on July } 1 \\
\text { and ending on June } 30 \text { ) and multiplied by } 100 \text {. Inventory data is the } \\
\text { number of systems active at least part of that fiscal year, and this } \\
\text { data (for 1994-2017) came from a request to EPA's Office of Ground } \\
\text { Water and Drinking Water. Using the calendar year for the number } \\
\text { of violations and the fiscal year for the inventory may lead to some } \\
\text { errors since they only have a 6-month period in common, however, } \\
\text { this likely does not affect long-term trends. }\end{array}$ \\
\hline Number of People Served & Sum of population served by each PWS in violation for a year. \\
\hline by Systems in Violation & Population served is provided for each PWS in SDWIS. \\
\hline Percent of People Served by & Number of people served by a CWS in violation for a year divided by \\
\hline Systems in Violation & $\begin{array}{l}\text { the total sum of people served by all CWS and multiplied by } 100 \text {. } \\
\text { Only CWS data was utilized for this percent calculation to avoid }\end{array}$ \\
\hline
\end{tabular}


Maximum Violation

Duration

Groundwater or Surface

Water Violations

Percent Groundwater or

Surface Water Violations

Number of Violations by

PWS Type
The maximum number of consecutive quarters in violation was calculated for each PWS between 2006 and 2017; number divided by four to convert to annual basis. Calculated by using the compliance period begin date to determine which quarter the violation occurred. Duration is not the same as time between the compliance begin date and compliance end date, which would measure how long a single violation lasts.

Number of PWS in violation having their source water listed as either ground water or surface water by SDWIS.

Number of groundwater or surface water systems in violation for a calendar year divided by the inventory of active systems with the respective source type for that fiscal year (beginning on July 1 and ending on June 30 ) and multiplied by 100 . This inventory data was acquired from EPA's Office of Ground Water and Drinking Water. Using the calendar year for the number of violations and the fiscal year for the inventory may lead to some errors since they only have a 6-month period in common, however, this likely does not affect long-term trends.

PWS were filtered by PWS type to calculate the number of systems in violations per year by PWS type. PWS types are: CWS, TNCWS, and NTNCWS. Since TNCWS are exempt from the Final Arsenic Rule, they were not included in this analysis. 
Percent Violations by PWS Type

(2)

Number of Violations by

Owner Type
Number of CWS or NTNCWS in violation for a calendar year divided by the inventory of active systems with the respective PWS type for that fiscal year (beginning on July 1 and ending on June 30) and multiplied by 100 . This inventory data was acquired from EPA's Office of Ground Water and Drinking Water. Using the calendar year for the number of violations and the fiscal year for the inventory may lead to some errors since they only have a 6-month period in common, however, this likely does not affect long-term trends.

PWS were filtered by owner type to calculate the number of systems in violation per year by owner type. Owner types are: Federal Government, Local Government, Native American, Private, Public/Private, and State Government. For a PWS with multiple owner types, the most common owner type was chosen.

\title{
Geographic Metrics
}

\author{
Mean Annual Number of \\ Average annual sum of number of systems in violation by state or \\ Violations per State or \\ county, from 2006 to 2017. Each violation is associated with a \\ County \\ state/primacy agency. The county served by each PWS was \\ obtained from the Geographic Area record in SDWIS, which is \\ separate from the violations data. The county served was merged \\ into the violations data by the PWS identifier, ensuring that each \\ PWS was associated with only one county.
}




\begin{tabular}{|c|c|}
\hline Mean Annual Population & Average annual number of people served by each PWS in violation \\
\hline Served per State or County & per state or county from 2006 to 2017. \\
\hline Mean Annual Number of & Average annual sum of number of systems in violation by state and \\
\hline GW or SW Violations per & by groundwater (GW) or surface water (SW) from 2006 to 2017. \\
\hline State & \\
\hline Mean Annual Percent of & The sum of violations per state and year was divided by the \\
\hline Systems in Violation by & inventory of active systems for that state and year and multiplied \\
\hline State & $\begin{array}{l}\text { by } 100 . \text { This percent in violation per state and year was then } \\
\text { averaged over all years, } 2006 \text { to } 2017 \text {. }\end{array}$ \\
\hline Mean Annual Percent of & The sum of people served per state and year was divided by the \\
\hline People Served per State & $\begin{array}{l}\text { inventory of all people served by active systems for that state and } \\
\text { year and multiplied by } 100 \text {. This percent of people served per state } \\
\text { and year was then averaged over all years, } 2006 \text { to } 2017 \text {. }\end{array}$ \\
\hline Mean Annual Monitoring & Average number of systems per state and per year with a \\
\hline and Reporting Violations & monitoring or reporting violation between 2006 and 2017. Listed in \\
\hline per State & $\begin{array}{l}\text { SDWIS as “(3) Monitoring, Regular" and “(4) Monitoring, } \\
\text { Check/Repeat/Confirmation." }\end{array}$ \\
\hline
\end{tabular}

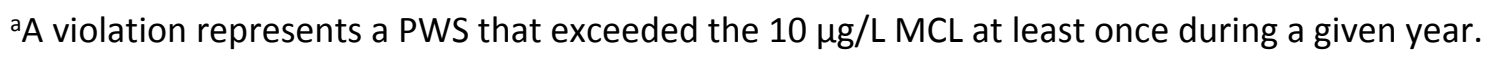

${ }^{\mathrm{b}} \mathrm{CWS}=$ community water system, NTNCWS = non-transient non-community water system, $\mathrm{TNCWS}=$ transient non-community water system, $\mathrm{MCL}=$ maximum contaminant level 
Table S2. Arsenic removal treatment methods incorporated into treatment analysis of violating systems and the average annual number of systems with arsenic violations reporting each treatment between 2013-2017. See footnotes $s^{\mathrm{a}, \mathrm{b}}$.

\begin{tabular}{|l|l|}
\hline Treatments Effective for Removing Arsenic & $\begin{array}{l}\text { Average Number of Systems Reporting } \\
\text { Treatment }\end{array}$ \\
\hline Ultraviolet Radiation & 5 \\
\hline Reverse Osmosis & 19.4 \\
\hline pH Adjustment, Pre & 6 \\
\hline pH Adjustment & 3.4 \\
\hline Permanganate & 5.6 \\
\hline Ozonation, Pre & 1 \\
\hline Microscreening & 0 \\
\hline Lime-Soda Ash Addition & 1.25 \\
\hline lon Exchange & 40.8 \\
\hline Filtration, Ultrafiltration & 0 \\
\hline Filtration, Greensand & 11.4 \\
\hline Filtered & 4.5 \\
\hline Electrodialysis & 0 \\
\hline Coagulation & 17.4 \\
\hline Activated Alumina & \\
\hline
\end{tabular}

Source: Environmental Protection Agency. Treatment technologies for arsenic removal [Internet]. 2005

[cited 2018 Mar 30]. Available from: https://nepis.epa.gov/Exe/ZyPDF.cgi/20017IDW.PDF?Dockey=20017IDW.PDF aSome newer technologies considered effective for arsenic removal are not included within the current treatment reporting system in SDIWS and so do not appear below.

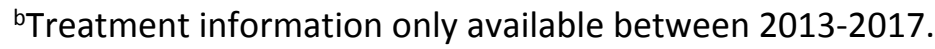


Table S3. Number and percent of violations and mean population served for all PWS by water source, PWS type, and owner type during period of 2006 to 2017. See footnotes ${ }^{\text {a-d }}$.

\begin{tabular}{|c|c|c|c|c|}
\hline & & Number of & & Mean Population \\
\hline Category & Type & Violations & $\%$ of Violations & Served per Year \\
\hline \multirow[t]{2}{*}{ All PWS } & - & 7,671 & 100 & 965,215 \\
\hline & Ground water & 7,387 & 96.30 & 700,579 \\
\hline \multicolumn{5}{|l|}{ Water source } \\
\hline & Surface water & 284 & 3.70 & 264,636 \\
\hline & CWS & 5,632 & 73.42 & 914,700 \\
\hline \multicolumn{5}{|l|}{ PWS type } \\
\hline & NTNCWS & 2,039 & 26.58 & 50,515 \\
\hline & Federal & & & \\
\hline & & 109 & 1.42 & 24,445 \\
\hline & government & & & \\
\hline & Local government & 2464 & 32.12 & 769,166 \\
\hline \multirow[t]{4}{*}{ Owner type } & Native American & 248 & 3.23 & 29,173 \\
\hline & Private & 4545 & 59.25 & 122,537 \\
\hline & Public/Private & 247 & 3.22 & 8,612 \\
\hline & State government & 58 & 0.76 & 11,282 \\
\hline
\end{tabular}

${ }^{a}$ The number of violations represents the total number of violations over the time period for each specified category.

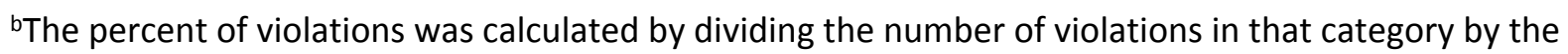
total number of violations over the time period and multiplying by 100.

${ }^{\mathrm{C}}$ Mean population served per year indicates the average number of people served per year by systems in violation within each specified category. Populations served by both CWS and NTNCWS are included in these calculations, which likely leads to overestimates as many people are served by both CWS and 
NTNCWS (i.e. CWS serving the home and NTNCWS serving the workplace). Mean population values were rounded up to the nearest integer if greater than 0.5 in the decimal place.

${ }^{d}$ CWS = Community water system, NTNCWS = Non-transient non-community system . 
Table S4. Mean annual number of systems in FAR violation and annual percent of systems in FAR violation by state within the conterminous US. See footnotes ${ }^{\mathrm{a}, \mathrm{b}}$.

\begin{tabular}{|c|c|c|c|c|}
\hline State & $\begin{array}{l}\text { Mean Annual } \\
\text { Number of } \\
\text { Systems in } \\
\text { Violation }\end{array}$ & $\begin{array}{l}\text { Mean Annual } \\
\text { Percent of } \\
\text { Systems in } \\
\text { Violation }\end{array}$ & $\begin{array}{c}\text { Standard } \\
\text { Deviation of } \\
\text { Annual Percent of } \\
\text { Systems in } \\
\text { Violation }\end{array}$ & $\begin{array}{l}\text { Range for Annual } \\
\text { Percent of } \\
\text { Systems in } \\
\text { Violation }\end{array}$ \\
\hline Alabama & NA & NA & NA & NA \\
\hline Arizona & 39.75 & 3.98 & 2.57 & $0.1-8.53$ \\
\hline Arkansas & 0.33 & 0.04 & 0.07 & $0-0.13$ \\
\hline California & 153.58 & 3.40 & 0.87 & $1.24-4.16$ \\
\hline Colorado & 2.00 & 0.19 & 0.15 & $0-0.4$ \\
\hline Connecticut & 4.67 & 0.41 & 0.25 & $0.09-0.85$ \\
\hline Delaware & 0.25 & 0.08 & 0.20 & $0-0.64$ \\
\hline Florida & 3.42 & 0.13 & 0.11 & $0-0.26$ \\
\hline Georgia & 1.75 & 0.09 & 0.12 & $0-0.4$ \\
\hline Idaho & 19.33 & 1.98 & 1.60 & $0.21-4.6$ \\
\hline Illinois & 18.83 & 0.87 & 0.49 & $0.32-1.67$ \\
\hline Indiana & 14.00 & 0.96 & 0.76 & $0.15-2.54$ \\
\hline lowa & 3.92 & 0.31 & 0.18 & $0.08-0.63$ \\
\hline Kansas & 4.83 & 0.52 & 0.32 & $0-0.85$ \\
\hline Kentucky & NA & NA & NA & NA \\
\hline Louisiana & 5.75 & 0.48 & 0.33 & $0-1.07$ \\
\hline
\end{tabular}




\begin{tabular}{|c|c|c|c|c|}
\hline Maine & 10.33 & 1.35 & 1.01 & $0.39-3.29$ \\
\hline Maryland & 4.25 & 0.40 & 0.41 & $0-1.58$ \\
\hline Massachusetts & 3.58 & 0.45 & 0.48 & $0-1.54$ \\
\hline Michigan & 29.42 & 1.02 & 1.47 & $0.18-5.33$ \\
\hline Minnesota & 7.25 & 0.49 & 0.38 & $0-1.33$ \\
\hline Mississippi & 0.08 & 0.01 & 0.03 & $0-0.09$ \\
\hline Missouri & 0.08 & 0.01 & 0.02 & $0-0.06$ \\
\hline Montana & 8.17 & 0.84 & 0.41 & $0-1.38$ \\
\hline Nebraska & 5.75 & 1.13 & 0.43 & $0.13-1.74$ \\
\hline Nevada & 8.50 & 4.02 & 2.18 & $0.29-7.81$ \\
\hline New Hampshire & 13.33 & 2.27 & 0.98 & $0.95-4.97$ \\
\hline New Jersey & 26.25 & 0.39 & 0.41 & $0-1.26$ \\
\hline New Mexico & 5.58 & 2.65 & 1.55 & $0.12-4.98$ \\
\hline New York & 20.25 & 0.34 & 0.14 & $0.16-0.56$ \\
\hline North Carolina & 11.42 & 0.02 & 0.03 & $0-0.08$ \\
\hline North Dakota & 0.50 & 0.53 & 0.78 & $0-2.25$ \\
\hline Ohio & 1.92 & 1.04 & 0.96 & $0.2-2.95$ \\
\hline Oklahoma & 21.83 & 0.67 & 0.15 & $0.43-0.98$ \\
\hline Oregon & 8.08 & 1.20 & 0.63 & $0.25-2.4$ \\
\hline Pennsylvania & 14.58 & 0.51 & 0.51 & $0.09-1.41$ \\
\hline Rhode Island & NA & NA & NA & NA \\
\hline South Carolina & 0.25 & 0.03 & 0.06 & $0-0.13$ \\
\hline South Dakota & 5.08 & 1.05 & 0.69 & $0.21-2.28$ \\
\hline
\end{tabular}




\begin{tabular}{|l|c|c|c|c|}
\hline Tennessee & NA & NA & NA & NA \\
\hline Texas & 97.75 & 1.76 & 0.25 & $1.39-2.16$ \\
\hline Utah & 1.67 & 0.31 & 0.85 & $0-2.95$ \\
\hline Vermont & 1.58 & 0.23 & 0.19 & $0-0.73$ \\
\hline Virginia & 2.50 & 0.14 & 0.09 & $0-0.3$ \\
\hline Washington & 7.83 & 0.30 & 0.50 & $0-1.7$ \\
\hline West Virginia & 0.58 & 0.10 & 0.11 & $0-0.34$ \\
\hline Wisconsin & 8.33 & 0.42 & 0.23 & $0.15-0.81$ \\
\hline Wyoming & 0.42 & 0.10 & 0.13 & $0-0.27$ \\
\hline
\end{tabular}

aStates with "NA" values had no recorded health-based violations during this period but did have monitoring or reporting violations (not shown here).

${ }^{\text {b} A l a s k a ~ a n d ~ H a w a i i ~ e x c l u d e d ~ f r o m ~ t h e ~ a n a l y s i s . ~}$ 
Table S5. The range of systems in FAR violation, the most recent number of systems in violation, and the percent reduction of the number of systems in violation per state within the conterminous US over the time period 2006-2017. See footnotes ${ }^{\mathrm{a}, \mathrm{b}}$.

\begin{tabular}{|c|c|c|c|c|}
\hline State & $\begin{array}{l}\text { Minimum Number } \\
\text { of Systems in } \\
\text { Violation }\end{array}$ & $\begin{array}{l}\text { Maximum Number } \\
\text { of Systems in } \\
\text { Violation }\end{array}$ & $\begin{array}{c}\text { Number of } \\
\text { Systems in } \\
\text { Violation in } 2017\end{array}$ & $\begin{array}{l}\text { Percent Reduction } \\
\text { from Peak Year to } \\
\text { Most Recent Year }\end{array}$ \\
\hline Alabama & NA & NA & NA & NA \\
\hline Arizona & 1 & 87 & 15 & 82.76 \\
\hline Arkansas & 0 & 1 & 0 & 100.00 \\
\hline California & 55 & 194 & 121 & 37.63 \\
\hline Colorado & 0 & 4 & 1 & 75.00 \\
\hline Connecticut & 1 & 10 & 1 & 90.00 \\
\hline Delaware & 0 & 2 & 0 & 100.00 \\
\hline Florida & 0 & 7 & 1 & 85.71 \\
\hline Georgia & 0 & 8 & 0 & 100.00 \\
\hline Idaho & 2 & 45 & 2 & 95.56 \\
\hline Illinois & 7 & 36 & 7 & 80.56 \\
\hline Indiana & 2 & 38 & 2 & 94.74 \\
\hline lowa & 1 & 8 & 1 & 87.50 \\
\hline Kansas & 0 & 8 & 2 & 75.00 \\
\hline Kentucky & NA & NA & NA & NA \\
\hline Louisiana & 0 & 13 & 5 & 61.54 \\
\hline Maine & 3 & 25 & 3 & 88.00 \\
\hline
\end{tabular}




\begin{tabular}{|c|c|c|c|c|}
\hline Maryland & 0 & 17 & 0 & 100.00 \\
\hline Massachusetts & 0 & 12 & 0 & 100.00 \\
\hline Michigan & 5 & 159 & 11 & 93.08 \\
\hline Minnesota & 0 & 20 & 6 & 70.00 \\
\hline Mississippi & 0 & 1 & 0 & 100.00 \\
\hline Missouri & 0 & 1 & 0 & 100.00 \\
\hline Montana & 0 & 13 & 5 & 61.54 \\
\hline Nebraska & 1 & 13 & 6 & 53.85 \\
\hline Nevada & 1 & 25 & 15 & 40.00 \\
\hline New Hampshire & 11 & 58 & 22 & 62.07 \\
\hline New Jersey & 0 & 18 & 0 & 100.00 \\
\hline New Mexico & 1 & 39 & 11 & 71.79 \\
\hline New York & 5 & 19 & 5 & 73.68 \\
\hline North Carolina & 0 & 2 & 0 & 100.00 \\
\hline North Dakota & 0 & 8 & 0 & 100.00 \\
\hline Ohio & 4 & 64 & 6 & 90.63 \\
\hline Oklahoma & 5 & 12 & 5 & 58.33 \\
\hline Oregon & 3 & 29 & 10 & 65.52 \\
\hline Pennsylvania & 3 & 47 & 3 & 93.62 \\
\hline Rhode Island & NA & NA & NA & NA \\
\hline South Carolina & 0 & 1 & 0 & 100.00 \\
\hline South Dakota & 1 & 11 & 2 & 81.82 \\
\hline Tennessee & NA & NA & NA & NA \\
\hline
\end{tabular}




\begin{tabular}{|l|c|c|c|c|}
\hline Texas & 77 & 120 & 81 & 32.50 \\
\hline Utah & 0 & 16 & 0 & 100.00 \\
\hline Vermont & 0 & 5 & 1 & 80.00 \\
\hline Virginia & 0 & 5 & 1 & 100.00 \\
\hline Washington & 0 & 44 & 0 & 97.73 \\
\hline West Virginia & 0 & 2 & 8 & 100.00 \\
\hline Wisconsin & 3 & 16 & 0 & 100.00 \\
\hline Wyoming & 0 & 1 & & \\
\hline
\end{tabular}

aStates with "NA" values had no recorded health-based violations during this period but did have monitoring or reporting violations (not shown here).

${ }^{b}$ Alaska and Hawaii excluded from the analysis. 


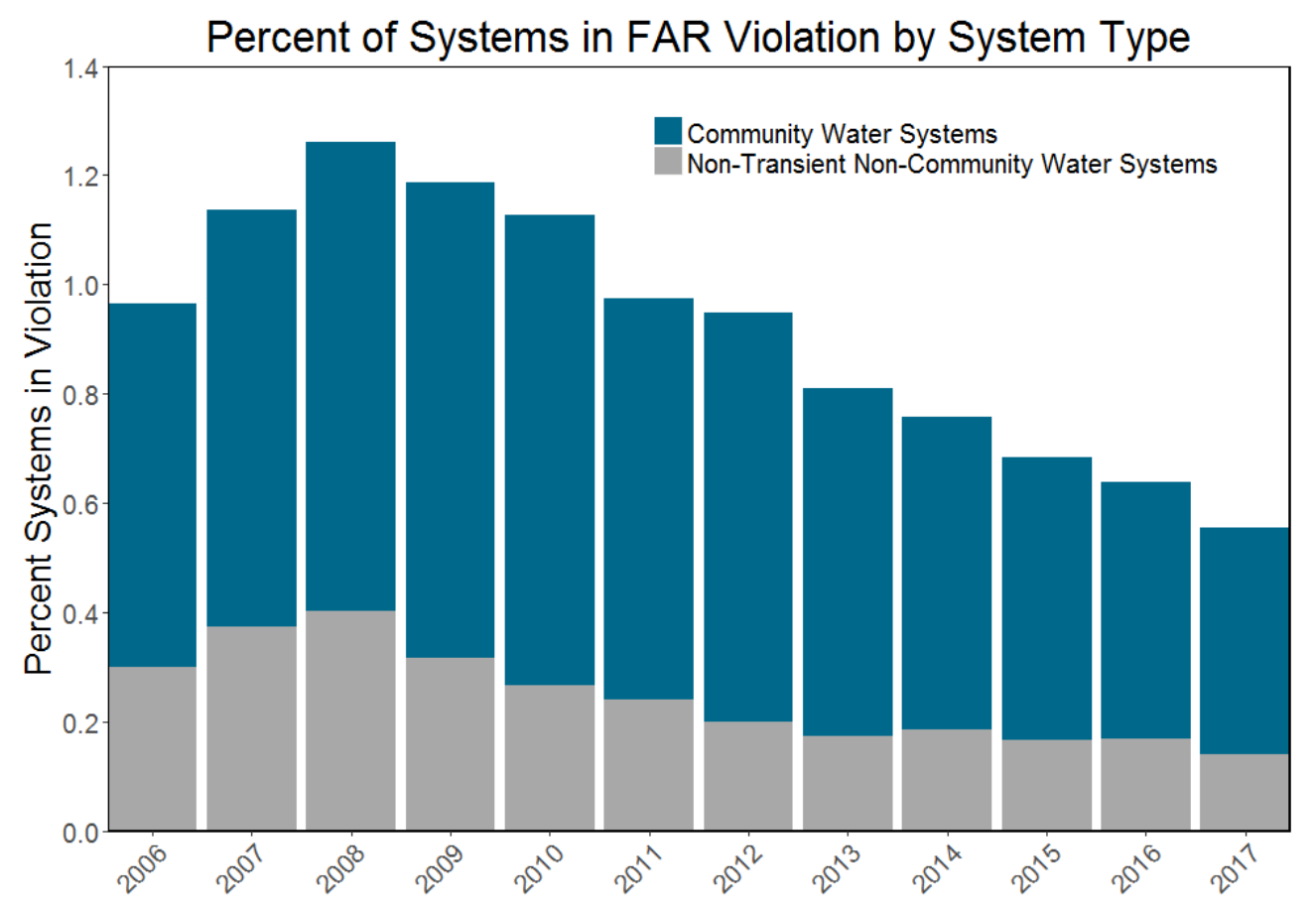

Figure S1. The percent of PWS (CWS and NTNCWS) in violation for arsenic (exceedance of MCL) by system type between 2006 and 2017. 


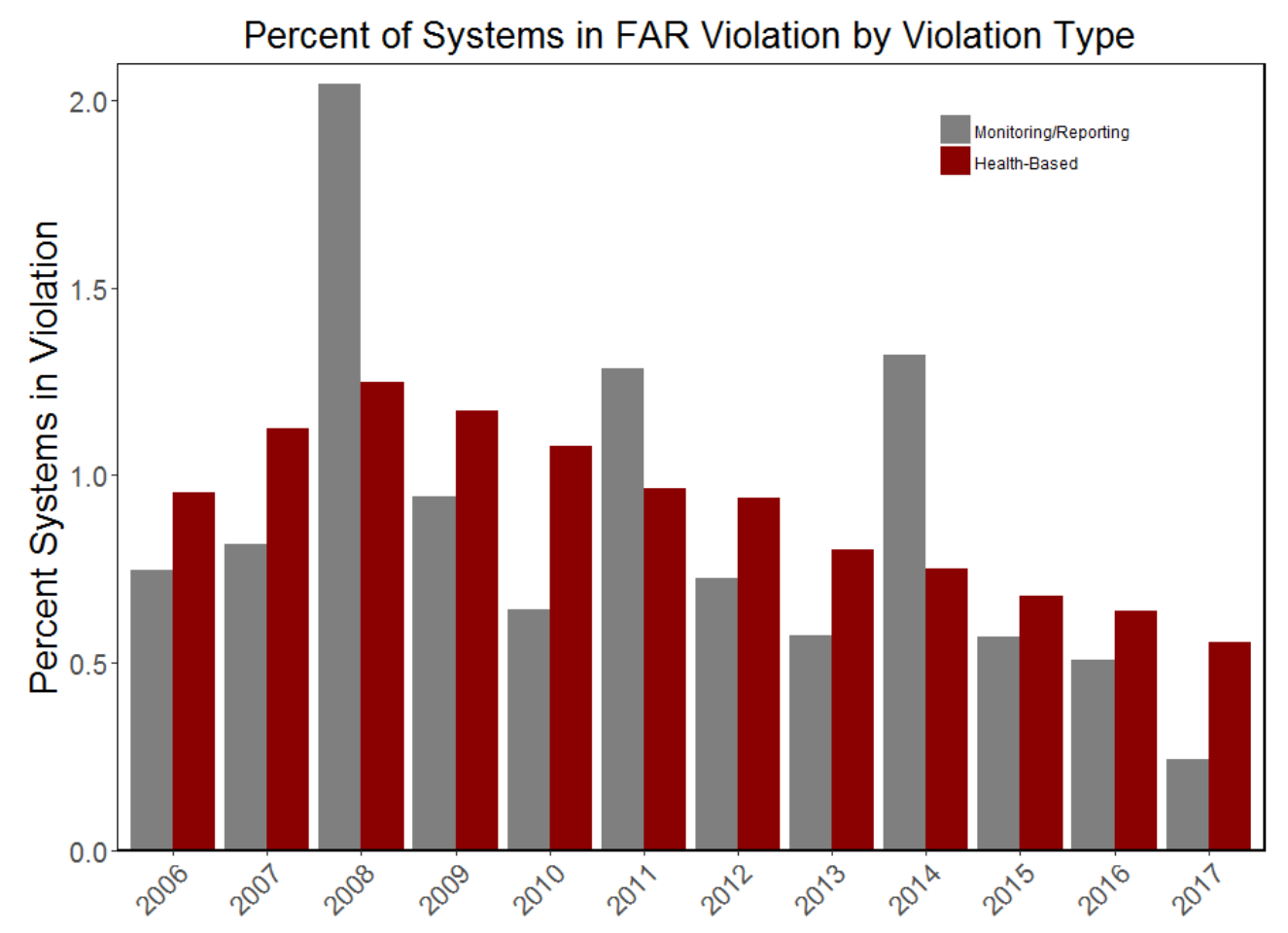

Figure S2. Comparison of the percent of PWS in FAR violation between 2006 and 2017 for either monitoring/reporting or a health-based violation (exceeding the $10 \mu \mathrm{g} / \mathrm{L} \mathrm{MCL}$ ). Both violation types demonstrate significant downward trends over time. Monitoring/Reporting: $p<0.05$, slope $=-0.054$; Health-Based: $p<0.001$, slope $=-0.070$. 


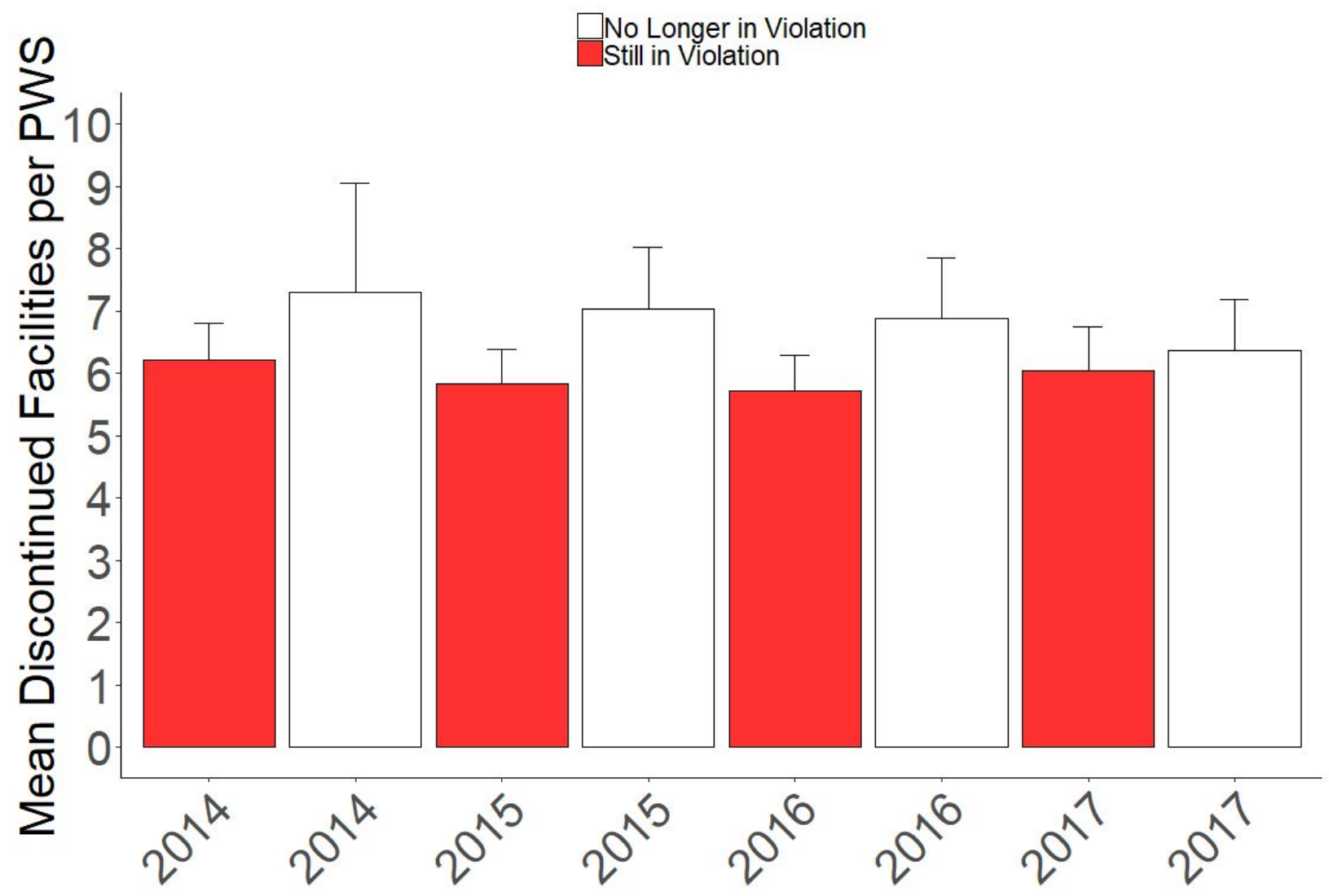

Figure S3. The mean number of discontinued facilities for PWS from 2014 to 2017, stratified by those in violation and those no longer in violation. Differences between groups each year were not significant. Year 2013 is not included as in other graphs (Figure 4b and 4c) because necessary facility inventory data is not available prior to 2013 and assessments are performed using the facilities of the prior year as the index. For example, the bars for year 2014 are for facilities that were active in 2013, but discontinued in 2014, while 2015 is looking at facilities active in 2014, but no longer active in 2015. 